\title{
TEORIA DAS JANELAS QUEBRADAS: UMA REFLEXÃO NO ORDENAMENTO JURÍDICO BRASILEIRO
}

Roberta Micheli de Oliveira Cavalcante, Olivie Samuel Paião

Universidade do Oeste Paulista - UNOESTE, Curso de Direito, Presidente Prudente, SP. E-mail: robertinhamo@hotmail.com

\section{RESUMO}

Este trabalho traz uma reflexão sobre a teoria das janelas quebradas, vislumbrando sua aplicabilidade no ordenamento jurídico brasileiro, haja vista a alta taxa de criminalidade existente, geradora de temor e insegurança. Utilizou-se, na metodologia, o método hipotético-dedutivo, analisando-se do geral para o particular. Abordar-se-á o instituto da criminologia, de forma sucinta, apontando seu conceito e finalidades, bem como no que se difere do direito penal. Feito o breve introito, a teoria das janelas quebradas será discutida a fim de compreendê-la, enfatizando sua origem e um paralelo de sua aplicação com relação entre a desordem e a criminalidade. Conclui-se o presente artigo, demonstrando a solidificação da aplicabilidade da teoria das janelas quebradas em nosso ordenamento jurídico brasileiro.

Palavras-chave: Janelas Quebradas, Criminalidade, Finalidades da Pena, Direito Penal, Ordenamento Jurídico.

\section{THEORY OF BROKEN WINDOWS: A REFLECTION IN BRAZILIAN LEGAL ORDER}

\section{ABSTRACT}

This work brings a reflection on the theory of broken windows, seeing its applicability in the Brazilian legal system, given the high crime rate, which generates fear and insecurity. The hypothetical-deductive method was used in the methodology, analyzing from the general to the particular. The institute of criminology will be approached in a succinct manner, pointing out its concept and purposes, as well as in what differs from criminal law. After the brief introduction, the theory of broken windows will be discussed in order to understand it, emphasizing its origin and a parallel of its application in relation to disorder and criminality. We conclude the present article, demonstrating the solidification of the applicability of broken window theory in our Brazilian legal system.

Keywords: Broken Windows, Criminality, Purpose of the Penalty, Criminal Law, Legal Planning.

\section{INTRODUÇÃO}

Atualmente, no mundo em que vivemos, nos deparamos com cenas de violência, presentes em nosso cotidiano. Infelizmente, tem se tornado rotina ver nos jornais e internet as mais variadas formas de crimes sendo cometidas, aumentandose, assim, o índice de criminalidade não só no Brasil, mas no mundo.

Em especial, no Brasil, vivemos em um cenário de corrupção, miséria e violência das mais variadas formas e um sistema de segurança pública totalmente ineficiente ante os infortúnios enfrentados, gerando insegurança física e jurídica para todos nós: o povo.

Tendo em vista esse acréscimo acelerado da criminalidade que tem como resultado o temor e insegurança das pessoas, oportuno se faz considerar uma nova estratégia diante deste cenário, com a finalidade de diminuir a incidência dos crimes, bem como combatê-los, por intermédio da Teoria das Janelas Quebradas.

Para que se possa melhor compreender a presente pesquisa, estruturou-se 0 presente artigo, com a introdução, a metodologia e, posteriormente, a discussão e a conclusão. Dessa forma, em síntese, abordou-se um breve conceito do que vem a ser a criminologia, objetos e finalidades, bem como as diferenças entre direito penal e criminologia, explanando-se, por conseguinte, o direito penal do equilíbrio.

Após, fez-se necessário abordar as teorias da pena, bem como suas finalidades, quais sejam: 
teoria absoluta ou da retribuição, teoria relativa, finalista, utilitária ou da prevenção e a teoria adotada pelo Código Penal Brasileiro.

Antes de se adentrar na conclusão, na discussão, de maneira mais específica, aprofundou-se o tema em estudo, versando sobre a teoria das janelas quebradas, a origem da teoria, a relação de causalidade entre a desordem e a criminalidade e a aplicabilidade da teoria das janelas quebradas no ordenamento jurídico brasileiro e por fim a conclusão.

$\mathrm{Na}$ elaboração da pesquisa, foram utilizadas pesquisas bibliográficas, análises de artigos científicos e legislações relacionadas à matéria abordada.

O principal objetivo da presente pesquisa é elucidar sobre a teoria das janelas quebradas e sua possível aplicação no ordenamento jurídico brasileiro.

\section{METODOLOGIA}

O artigo respaldou-se em pesquisas bibliográficas, das quais resultaram a leitura e análise de leis, resoluções e artigos eletrônicos. As informações foram analisadas e confrontadas com uso da dialética e a análise dos dados foi realizada com a aplicação do método hipotéticodedutivo, isto é, partindo do geral para o particular.

\section{DISCUSSÃO}

Com a violência iminente em todo o mundo, os números e índices de criminalidade foram automaticamente modificados. Mas para melhor se entender, cabe tecer um breve comentário do que vem a ser a criminalidade.

Nos dizeres de Lyra (1995, p. 51) a "Criminalidade é o conjunto dos crimes socialmente relevantes e das ações e omissões que, embora não previstas como crimes, merecem reprovação máxima".

Assim, sob essa ótica, é um fenômeno social complexo. A criminalidade deriva de um conjunto de elementos que, dentro de sua abordagem, o menos crucial é o direito e a legislação penal. A criminologia é o estudo experimental do fenômeno do crime, para lhe pesquisar a etiologia e tentar a sua debelação por meios retificativos ou curativos e preventivos. (HUNGRIA, 1963).

Sua origem se deu no século XVIII, com a vinda da denominada "Escola Clássica" da criminologia, por meio da obra de Beccaria (Dei Delitti e delle Pene) e demais filósofos, instigados pela teoria de Rousseau, na qual, asseguravam que a procedência do crime está na sociedade e em seus valores e erros.

Para os clássicos o homem é um ser livre e racional, podendo tomar decisões e arcar com suas consequências.

Nos dizeres de Maíllo (2008, p. 63):

Quando alguém encara a possibilidade de cometer um delito, efetua um cálculo racional, dos benefícios esperados (prazer) e os confronta com os prejuízos (dor) que acredita vão derivar da prática dos delitos; se os benefícios são superiores aos prejuízos, tenderá a cometer a conduta delitiva.

Posterior ao surgimento da "Escola Clássica" nasceu na ciência da criminologia uma segunda linha de pensamento, titulada como "Escola Positivista", derivada dos estudos do italiano Cesare Lombroso, criador da Escola Italiana de Criminologia Positivista. $\mathrm{Na}$ inspiração de suas ideias fixam-se conceitos oriundos da psiquiatria, do Darwinismo Social e Eugenia. Em outras palavras, sua abordagem visava a extinguir o gene criminoso, livrando a sociedade do crime, por meio de uma fusão entre causa e efeito (AGUIAR, 2013).

A criminologia positivista teve seu marco inicial através da obra "L'uomo Delinquente", de 1876, de Lombroso, tendo como destaque a pessoa do criminoso nato, com enfoque em sua condição genética, sendo prontamente reconhecido por falhas ou deformidades físicas.

Nesse contexto, no final do século XIX, surge uma terceira escola criminológica, conhecida como "Escola Sociológica", trazendo pensamentos distintos das outras correntes conflitantes da criminologia. Com ênfase na condição de vivência social do criminoso, tais como: baixo nível educacional, condições econômicas precárias, entre outros.

$\mathrm{Na}$ atualidade, os estudos da criminologia predominam sob as circunstâncias biopsicossociais do criminoso, englobando parte das três escolas.

Shecaira (2004, p. 37) aponta:

(...) a criminologia, além de requerer consideráveis esforços, exige profundos 
conhecimentos psicológicos e sociológicos, por ser uma disciplina que trabaIha com métodos diferentes daqueles normalmente utilizados na esfera jurídico-penal.

Gomes, (apud PABLOS DE MOLINA, 2002, p. 37), conceitua criminologia como sendo, "uma ciência empírica e interdisciplinar, que se ocupa do estudo do crime, da pessoa do infrator, da vítima e do controle social do comportamento delitivo".

Nesse sentido, define-se como sendo uma ciência que busca elementos que se aproximem do fato delitivo, levando em consideração as condições sociais, culturais, políticas e econômicas.

\section{DIFERENÇA ENTRE DIREITO PENAL E CRIMINOLOGIA}

Trata-se a Criminologia de uma ciência empírica do crime, colaborando com o Direito Penal, que tem como função buscar a essência e causa do delito e o estudo da personalidade do delinquente. Contudo, o Direito Penal não deixa de ser uma ciência de coibição social em face daquele que comete um delito, cuja violação das regras determinadas implica em sanções.

Frisa-se que tanto o Direito Penal quanto a Criminologia dedicam-se a estudar o crime, todavia, o fazem com perspectivas diferentes.

De acordo com Penteado Filho, o Direito Penal conceitua crime como sendo conduta típica, antijurídica e culpável e a Criminologia, por sua vez, ocupa-se em estudar não só o crime, mas trata também de quatro vertentes: delito, delinquente, vítima e controle social (PENTEADO FILHO, 2012).

Nesse sentido, a criminologia difere do Direito Penal por ser uma ciência causalexplicativa, que tem por objeto a responsabilidade de se atentar não somente ao crime, mas também conhecer a figura do criminoso, buscando evidenciar fatores determinantes da criminalidade, assim como responder às razões pelas quais o homem se torna propenso a cometer atos criminosos (SOARES, 2003).

\section{DIREITO PENAL DO EQUILÍBRIO}

O Direito Penal do Equilíbrio é compreendido por seu posicionamento minimalista do Direito Penal, e nesse contexto se interpõe entre duas extremidades. Preliminarmente fazendo menção ao abolicionismo penal, tendo por desígnio buscar a finalidade do Direito Penal, e depois em outro ângulo o movimento de lei e ordem, trazendo como assertividade o emprego de um Direito Penal Máximo.

Assim sendo, o designado Direito Penal do Equilíbrio almeja resolver os embates de interesses sociais com integridade, de forma a proteger os bens estimados de maior importância para a convivência no meio social.

\section{FINALIDADES DA PENA}

A pena é uma das sanções impostas pelo Estado ao culpado, pela prática de uma infração penal, que se dá por meio de uma ação penal, sob o manto do devido processo legal.

Capez (2010, p. 601) aduz que "a finalidade da pena é punir o autor de uma infração penal. A pena é a retribuição do mal injusto, praticado pelo criminoso, pelo mal justo previsto no ordenamento jurídico".

Silva (2002, p. 35) pontua que "há basicamente três teorias que buscam justificar a cominação e a aplicação da pena: a absoluta ou retributiva, a relativa ou preventiva e a teoria mista ou eclética".

Deste modo, Silva (2002, p. 35) ressalta:

Pela teoria absoluta ou retributiva, a pena apresenta a característica de retribuição, de ameaça de um mal contra o autor de uma infração penal. A pena não tem outro propósito que não seja o de recompensar o mal com outro mal. Logo, objetivamente analisada, a pena na verdade não tem finalidade. É um fim em si mesma.

De outra banda, a teoria relativa ou da prevenção é compreendida como sendo um meio de prevenir a prática de delitos, evitando-se a reiteração, presando a prevenção geral (MARTINS, 2014).

A prevenção geral visa a intimidação da sociedade para que não haja a reincidência da prática do delito, já a prevenção especial tem como objeto o próprio infrator, e sua finalidade é o ressocializar para que ele não volte a delinquir (CAPEZ, 2010). 
Por fim, a teoria adotada pelo nosso Código Penal Brasileiro é a mista ou unificadora da pena, tendo, inclusive, previsão no art. 59, deste código. Essa consiste em aplicar pena ao infrator/criminoso, mas também prevenir a prática reiterativa, por intermédio de sua ressocialização na sociedade, reeducação e intimidação coletiva, conforme acrescenta Capez (2010).

\section{TEORIA DAS JANELAS QUEBRADAS}

A "broken windows theory" ou teoria das janelas quebradas é uma referência norteamericana de regime de segurança pública e combate à criminalidade, surgiu com estudos dos cientistas americanos James Q. Wilson e George Kelling. Tal teoria apresenta a desordem como um dos elementos de maior fator dos índices da criminalidade (OLIVEIRA, 2016).

Seu ponto de partida se dá a partir de uma experiência desenvolvida pela Universidade de Stanford (EUA), pertinente à psicologia social.

Deste modo, deixaram dois carros iguais, do mesmo modelo, cor e marca, abandonados na rua. O primeiro no Bronx, um bairro desprovido e conflituoso de Nova York e o segundo em Palo Alto, um bairro tranquilo e abastado da Califórnia.

Logo, perceberam que o carro abandonado no Bronx foi prontamente deteriorado, levando-se tudo o que era possível. Em contrapartida, o carro abandonado em Palo Alto, continuou intacto.

Diante do resultado obtido, os pesquisadores resolveram fazer outro teste, abandonando mais uma vez, um carro em Palo Alto, contudo, dessa vez, com um de seus vidros quebrados. Perceberam então, que o resultado foi exatamente igual ao do carro abandonado no Bronx.

Com base nas pesquisas realizadas, chegaram à conclusão de que o ato de vandalismo praticado em ambos os carros, ainda que em bairros distintos, não possui relação com a classe social, trata-se de uma questão de psicologia humana e relações sociais (PELLEGRINI, 2013).

Assim sendo, com base nessa pesquisa, foi construída a Teoria das Janelas Quebradas. Através do entendimento de que o delito tende a ser maior em locais em que o descuido se torna evidente, passando uma sensação de que naquele local a norma é ausente.

Acerca desse entendimento, a respeito da relação direta entre a desordem e a criminalidade, dispõe Moura Junior (2015, p. 287):
É natural, em um primeiro momento analisarmos 0 abandono como forma de taxarmos a área como despreocupada em manter os códigos de convivência, bem como de um ponto de vista criminalístico defendermos a máxima de que nas áreas onde há sujeira, se verificarmos abandono, a desordem, podemos concluir que os delitos são maiores, ou que a possibilidade de crimes e delitos, mesmo que sejam de menor potencial ofensivo são verificados com maior veemência.

Nesse contexto, preconiza que, se não forem contidos os pequenos delitos ou contravenções, logo, conduzirão a condutas criminosas mais graves, em decorrência do descaso estatal em aplicar sanções aos infringentes, pelos crimes menos gravosos.

Segundo Foucalt (1987, p. 275, apud MOURA JUNIOR, 2015, p. 287): “A mínima desobediência é castigada e o melhor meio de evitar delitos graves é punir muito severamente as mais leves faltas".

De acordo com Sumariva (2014), o objetivo da teoria é "promover a redução dos índices de criminalidade e evitar que um determinado local se torne uma zona de concentração da criminalidade".

Nesse sentido, a teoria das janelas quebradas fundamenta-se na punição de pequenos delitos, no intuito de prevenir delitos futuros.

Episódios de desordem e de crimes de menor potencial ofensivo quando não são cuidados na sua origem degeneram para um processo de violência cada vez maior, chegando a um ponto em que parece não haver solução, sob passividade e/ou incompetência dos órgãos de segurança pública e dos homens que lideram na política, tanto no poder executivo quanto no poder legislativo e também no poder judiciário que cuidam da segurança pública no nosso país.

Fato é que olhamos o Brasil como uma enorme janela quebrada em que nos repelimos a reparar. A nossa neutralidade transformada em indignação seletiva e momentânea permite que a desordem e a criminalidade prosperem e se tornem mais frequentes e violentas. 
Desse modo, a aplicabilidade da teoria das janelas quebradas no Brasil possui o condão de punir pequenos delitos que possivelmente acarretariam outros delitos maiores (OLIVEIRA, 2016).

Nesse sentido Kelling e Wilson sugerem que, se a desordem não for logo combatida e interrompida, a criminalidade resultante dela será ainda maior e mais violenta (COUTINHO, 2009).

\section{CONCLUSÃO}

A teoria das janelas quebradas, elaborada pelos estudos dos criminologistas americanos James Q. Wilson e George Kelling apontam a criminalidade como um fator decorrente da desordem.

Esta teoria definiu um novo marco no estudo da criminalidade ao distinguir que a relação de causalidade entre a criminalidade, tais como a pobreza ou a segregação racial é menos importante do que a relação entre a desordem e a criminalidade.

Apregoa tal teoria que devem ser punidos os pequenos delitos para que não evoluam e se tornem mais gravosos. A teoria das janelas quebradas visa gerar a redução dos índices de criminalidade e evitar que em determinada região haja concentração de delinquentes. Trata-se de uma estratégia para combater a criminalidade. $\mathrm{O}$ que se pretende é uma possível aplicação de um modelo adequado de gestão, em consonância com os direitos fundamentais expostos, em busca de uma sociedade justa e digna para se viver.

Nesse sentido, entende-se que é possível sim a aplicação de tal teoria no ordenamento jurídico brasileiro, de modo que, embora os pequenos delitos não causem maior lesão ao bem jurídico, entende-se que não devem ser ignorados.

Em razão desse entendimento, propõe-se a aplicação de efetivas políticas públicas de prevenção e repressão a pequenos delitos, podendo, inclusive, serem aplicadas através de prestação de serviços comunitários, que se mostra meio eficaz de punibilidade, asseverando a presença do Estado, sem que este precise atuar de modo radical, privando os pequenos infratores ou baderneiros de sua liberdade.

\section{REFERÊNCIAS}

CAPEZ, F. Curso de direito penal - parte geral. 11. ed. São Paulo: Saraiva, 2006. v. 1.
HUNGRIA, N. Direito penal e criminologia. Revista Brasileira de Criminologia e Direito Penal, São Paulo, 1963.

LYRA, R. Criminologia dialética. Rio de Janeiro: Borsoi, 1964.

MAÍLLO, S.A. Introdução à criminologia. São Paulp: Ed. Revista dos Tribunais, 2008.

MARTINS, J. Das teorias da pena no ordenamento jurídico brasileiro. 2014. Disponível em: https://joaomartinspositivado.jusbrasil.com.br/ar tigos/147934870/das-teorias-da-pena-noordenamento-juridico-brasileiro. Acesso em: 01 Abr. 2018.

MOURA JUNIOR, O. Teoria das janelas quebradas $x$ tolerância zero. In: GRECO, A. O. P. (Org.). Direito Penal avançado: homenagem ao professor Dirceu de Mello. Curitiba: Juruá, 2015.

OLIVEIRA, R. Teoria das janelas quebradas e sua aplicabilidade no ordenamento jurídico brasileiro. 2016. Disponível em: https://rodolfoliveira.jusbrasil.com.br/artigos/391 494010/teoria-das-janelas-quebradas-e-suaaplicabilidade-no-ordenamento-juridicobrasileiro. Acesso em: 19 Abr. 2018.

PABLOS DE MOLINA, A.G. Criminologia: uma introdução a seus fundamentos teóricos. 3. ed. São Paulo: Revista dos Tribunais, 2002.

PENTEADO FILHO, N.S. Manual esquemático de criminologia. 2. ed. São Paulo: Saraiva, 2012.

SHECAIRA, S.S. Criminologia. São Paulo: Ed. Revista dos Tribunais, 2004.

SILVA, H.C. Manual de execução penal. 2. ed. Campinas: Bookseller, 2002.

SOARES, O. Curso de criminologia. Rio de Janeiro : Forense, 2003.

SUMARIVA, P. Criminologia: teoria e prática. 2. ed. Niterói: Impetus, 2014.

Recebido para publicação em 30/03/2018

Revisado em 13/09/2018

Aceito em 19/09/2018 